\section{Unusual pedunculated gastric polypoid lesion}

A 60-year-old woman was referred to our department for an incidental finding of gastric polypoid lesion on enhanced CT (E-CT) (figure 1A). She had a medical history of hepatocellular carcinoma (HCC) treated 3 years prior with transcatheter arterial chemoembolisation. E-CT is routinely performed once a year for the surveillance post HCC therapy. No obvious recurrence was detected in the liver. Upper gastrointestinal endoscopy revealed a $30 \mathrm{~mm}$ pedunculated gastric polypoid lesion on the greater curvature of the antrum (figure 1B).

All blood test results were nearly normal: haemoglobin, $11.2 \mathrm{~g} / \mathrm{dL}$; platelets, $125000 / \mathrm{mm}^{3}$; bilirubin, $0.7 \mathrm{mg} / \mathrm{dL}$; aspartate aminotransferase, $51 \mathrm{U} / \mathrm{L}$; alanine aminotransferase, $39 \mathrm{U} / \mathrm{L}$; alkaline phosphatase, $166 \mathrm{U} / \mathrm{L}$; gamma-glutamyl transpeptidase, $32 \mathrm{U} / \mathrm{L}$; and prothrombin index, 98\%; alpha-fetoprotein, 62 ng/ $\mathrm{mL}$; des-gamma-carboxy prothrombin, $37 \mathrm{mAU} / \mathrm{mL}$. The hepatitis $C$ virus had been eliminated 6 months before this examination and the test for hepatitis $B$ virus was negative. Endoscopic ultrasonography revealed a heterogeneous and hypoechoic internal echo. There was no obvious tumour invasion into the muscular layer. Therefore, endoscopic submucosal dissection (ESD) was performed for pedunculated polypoid lesion resection (figure 1C).

\section{QUESTION}

What is the diagnosis?

\section{ANSWER}

Gastric metastasis from HCC.

Histological analysis after ESD revealed pedunculated gastric metastasis from HCC (figure 2A) with CK20 (+) (figure 2B), hepatocyte (+) (figure 2C), and CK7 (-), ly (+), v (+), HM0 and VM0; hence, anticancer therapy was initiated. She was discharged 5 days postoperatively.

Gastric metastasis from HCC is extremely rare. In most of those cases, gastric metastasis was detected
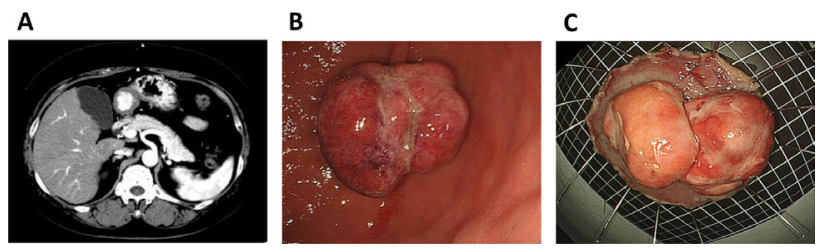

Figure 1 CT scan revealing a gastric hypervascular tumour in the stomach (A). Upper gastrointestinal endoscopy showing a $30 \mathrm{~mm}$ pedunculated gastric polypoid lesion on the greater curvature of the antrum (B). Endoscopic submucosal dissection was performed for pedunculated polypoid lesion resection (C).
A
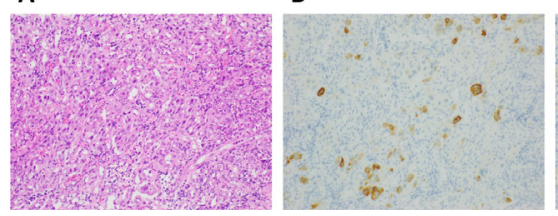

Figure 2 Histological findings after endoscopic submucosal dissection revealed pedunculated gastric metastasis from hepatocellular carcinoma (A) with CK20 (+) (B), hepatocyte (+) (C).

using $\mathrm{CT},{ }^{1}$ upper gastrointestinal bleeding ${ }^{2}$ or autopsy. ${ }^{3}$ In this study, we accidentally detected a gastric hypervascular tumour in the stomach using dynamic CT (figure 1A). Regarding the transfer form to the stomach from the liver, direct invasion was mainly detected. Patients with gastric metastasis often undergo surgical resection- $12^{1}$ or transcatheter chemoembolisation. ${ }^{2}$ In our case, the shape of the gastric metastatic lesion was unusual: the pedunculated polypoid type. The patient also underwent ESD, since the depth of invasion seemed submucosal on the pre-ESD endoscopic ultrasonography. This lesion was solitary metastasis and serum AFP level became normal after ESD. No obvious recurrence was detected in this lesion 6-12 months following ESD.

To our knowledge, this is the first report wherein ESD was performed for pedunculated gastric metastasis from HCC. Our case suggests that an enhanced gastric tumour after HCC treatment could be metastasis from HCC and a careful approach is essential to prevent gastrointestinal bleeding.

\section{Asahiro Morishita ๑ , Joji Tani, Tsutomu Masaki}

Gastroenterology and Neurology, Kagawa University Faculty of Medicine Graduate School of Medicine, Kita-gun, Kagawa, Japan

Correspondence to Dr Asahiro Morishita, Gastroenterology and Neurology, Kagawa University Faculty of Medicine Graduate School of Medicine, Kita-gun 761-0793, Japan; asahiro@med.kagawa-u.ac.jp

Acknowledgements The authors thank Kyoko Oura and Tomoko Tadokoro for the technical assistance.

Contributors AM and JT treated a patient and collected data. AM wrote a draft and TM revised it.

Funding The authors have not declared a specific grant for this research from any funding agency in the public, commercial or not-for-profit sectors.

Competing interests None declared.

Patient consent for publication Obtained.

Provenance and peer review Not commissioned; externally peer reviewed.

\section{(2) OPEN ACCESS}

Open access This is an open access article distributed in accordance with the Creative Commons Attribution Non Commercial (CC BY-NC 4.0) license, which permits others to distribute, remix, adapt, build upon this work noncommercially, and license their derivative works on different terms, provided the original work is properly cited, appropriate credit is given, any changes made indicated, and the use is non- 
commercial. See: http://creativecommons.org/licenses/by-nc/4. $0 /$.

(C) Author(s) (or their employer(s)) 2021. Re-use permitted under CC BY-NC. No commercial re-use. See rights and permissions. Published by BMJ.

\section{A) Check for updates}

To cite Morishita A, Tani J, Masaki T. Frontline Gastroenterology Epub ahead of print: [please include Day Month Year]. doi:10.1136/flgastro-2020-101700

Received 9 October 2020

Revised 29 October 2020

Accepted 1 November 2020

Frontline Gastroenterology 2021;0:1-2. doi:10.1136/flgastro-2020-101700
ORCID ID

Asahiro Morishita http://orcid.org/0000-0002-0760-3045

\section{REFERENCES}

1 Haruki K, Misawa T, Gocho T, et al. Hepatocellular carcinoma with gastric metastasis treated by simultaneous hepatic and gastric resection: report of a case. Clin J Gastroenterol 2016;9:319-23.

2 Imai M, Ishikawa T, Okoshi M, et al. Hemorrhagic gastric metastasis from hepatocellular carcinoma successfully treated using coil embolization of the left gastric artery. Intern Med 2019;58:2179-83.

3 Hatano K, Kita R, Sakamoto Y, et al. [Case of moderately differentiated hepatocellular carcinoma with gastric metastasis]. Nihon Shokakibyo Gakkai Zasshi 2008;105:404-11. 